\title{
PEMODELAN JUMLAH KASUS PENYAKIT KUSTA DI PROVINSI JAWA TIMUR
}

\author{
Ni Made Sukma Pertiwi ${ }^{1 \S}$, I Komang Gde Sukarsa ${ }^{2}$, Made Susilawati ${ }^{3}$ \\ ${ }^{1}$ Program Studi Matematika, Fakultas MIPA - Universitas Udayana [Email: sukmapertiwi85@ gmail.com] \\ ${ }^{2}$ Program Studi Matematika, Fakultas MIPA - Universitas Udayana [Email: gedesukarsa@unud.ac.id] \\ ${ }^{3}$ Program Studi Matematika, Fakultas MIPA - Universitas Udayana [Email: mdsusilawati@unud.ac.id] \\ ${ }^{\S}$ Corresponding Author
}

\begin{abstract}
Spatial Autoregressive Model (SAR) is a combination of linear regression models with spatial lag in response variables that consider spatial effects. One problem that considers spatial effects is leprosy cases. This study aims to predict the number of leprosy cases models in East Java Province and the factors that influence it. The type of data used in this study is secondary data obtained from the publication of the Health Profile of East Java Province in 2017 and the publication of the Central Statistics Agency (CSA) of East Java Province. The results of this study indicate that the SAR model can describe the number of leprosy cases in East Java Province with AIC value is 109,951 and $R^{2}$ value is $71,93 \%$. The factors that influence the number of leprosy cases are the percentage of healthy houses and the number of health centers in each district/city in East Java Province.
\end{abstract}

Keywords: Leprosy, Spatial Effects, SAR

\section{PENDAHULUAN}

Analisis regresi adalah salah satu teknik analisis data yang digunakan untuk melihat hubungan antara variabel respons dengan variabel bebas. Apabila dalam analisis regresi ditemukan adanya unsur spasial pada data yang dianalisis, maka regresi tersebut dinamakan regresi spasial. Regresi spasial merupakan pengembangan dari analisis regresi yang bertujuan untuk melihat hubungan antara variabel bebas dan variabel respons dengan adanya tambahan berupa informasi spasial (ruang/lokasi) pada data variabel respons, sehingga dalam menganalisis data tersebut harus mempertimbangkan efek spasial. Secara umum, model regresi spasial dapat ditulis sebagai

$$
\mathbf{y}=\rho \mathbf{W}_{1} \mathbf{y}+\mathbf{X} \boldsymbol{\beta}+\lambda \mathbf{W}_{\mathbf{2}} \mathbf{v}+\boldsymbol{\varepsilon}
$$

dengan $\mathbf{y}$ adalah variabel respons, $\rho$ adalah koefisien lag spasial pada variabel respons, $\mathbf{W}_{\mathbf{1}}$ dan $\mathbf{W}_{\mathbf{2}}$ adalah matriks pembobot spasial, $\mathbf{X}$ adalah variabel bebas, $\boldsymbol{\beta}$ adalah parameter koefisien regresi, $\lambda$ adalah koefisien lag spasial pada error, $\mathbf{v}$ adalah galat (sisaan) yang diasumsikan berautokorelasi, dan $\boldsymbol{\varepsilon}$ adalah galat (sisaan).

Spatial Autoregressive (SAR) merupakan model yang menggabungkan antara model regresi linear dan lag spasial pada variabel respons dengan menggunakan data cross section (Anselin, 1988). Pada Spatial Autoregressive (SAR), proses autoregresif diasumsikan terjadi hanya pada variabel respons. Model Spatial Autoregressive (SAR) terbentuk apabila pada persamaan (1) nilai $W_{2}=0$ dan $\lambda=0$, yang dinyatakan sebagai (Anselin, 1988)

$$
\mathbf{y}=\rho \mathbf{W}_{\mathbf{1}} \mathbf{y}+\mathbf{X} \boldsymbol{\beta}+\boldsymbol{\varepsilon}
$$

dengan $\mathbf{y}$ adalah variabel bebas dengan matriks berukuran $n \times 1, \quad \mathbf{X}$ adalah variabel bebas dengan matriks berukuran $n \times p, \mathbf{W}_{\mathbf{1}}$ adalah matriks pembobot spasial berukuran $n \times n, \rho$ adalah koefisien spasial lag $\left(\mathbf{W}_{\mathbf{1}} \mathbf{y}\right), \boldsymbol{\beta}$ adalah parameter koefisien regresi dengan matriks berukuran $p \times 1$ dan $\boldsymbol{\varepsilon}$ adalah galat (sisaan) dengan matriks berukuran $n \times 1$.

Pada tahun 2017, jumlah kasus kusta tertinggi di Indonesia terdapat di Provinsi Jawa Timur. Berdasarkan data Dinas Kesehatan Provinsi Jawa Timur (2018), pada tahun 2016 tercatat jumlah kasus penyakit kusta di Jawa Timur sebanyak 4.008 kasus sedangkan pada tahun 2017 tercatat sebanyak 3.543 kasus. Jumlah kasus penyakit kusta yang tercatat di 
tahun 2017 mengalami penurunan dari tahun sebelumnya. Namun masih terdapat beberapa kabupaten yang mengalami peningkatan kasus penyakit kusta di Provinsi Jawa Timur.

Peneliti menduga bahwa kondisi geografis di Jawa Timur memengaruhi penyebaran penyakit kusta, sebab adanya kedekatan antara daerah satu dengan daerah lainnya akan memengaruhi penyebaran penyakit kusta. Sehingga dalam menganalisis kasus tersebut digunakan analisis regresi spasial, salah satunya yaitu metode Spatial Autoregressive (SAR).

Penelitian sebelumnya tentang Spatial Autoregressive telah dilakukan oleh Dewi, dkk (2017) yang meneliti masyarakat yang berperilaku MCK di sungai di Kecamatan Blahbatuh. Penelitian tersebut menghasilkan faktor-faktor yang berpengaruh secara signifikan adalah jumlah KK yang belum memiliki jamban dan jumlah KK yang tinggal dekat sungai. Selain itu, penelitian sebelumnya tentang penyakit kusta dilakukan oleh Ernawati, dkk (2016) yang meneliti angka prevalensi penyakit kusta di Jawa Timur menggunakan Spatial Durbin Model. Penelitian tersebut menghasilkan faktor-faktor yang berpengaruh signifikan adalah persentase rumah tangga berperilaku hidup bersih dan sehat (PHBS), kepadatan penduduk, persentase penduduk miskin, dan persentase puskesmas.

Tujuan dari penelitian ini adalah untuk memodelkan jumlah kasus penyakit kusta menggunakan metode SAR serta untuk mengetahui faktor-faktor yang berpengaruh signifikan terhadap jumlah kasus penyakit kusta di Provinsi Jawa Timur.

\section{METODE PENELITIAN}

Data yang digunakan dalam penelitian ini berupa data sekunder yang diperoleh dari publikasi Profil Kesehatan Provinsi Jawa Timur tahun 2017 dan data publikasi dari Badan Pusat Statistik Provinsi Jawa Timur. Variabel respons pada penelitian ini adalah jumlah kasus penyakit kusta di setiap kabupaten/kota di Provinsi Jawa Timur $(Y)$. Variabel bebas pada penelitian ini adalah kepadatan penduduk $\left(X_{1}\right)$, persentase rumah tangga berPHBS $\left(X_{2}\right)$, persentase rumah sehat $\left(X_{3}\right)$, persentase penduduk miskin $\left(X_{4}\right)$, persentase penduduk usia 15 tahun ke atas dengan pendidikan terakhir SD $\left(X_{5}\right)$, dan jumlah puskesmas $\left(X_{6}\right)$ di setiap kabupaten/ kota di Provinsi Jawa Timur.

Metode analisis yang digunakan pada pe- nelitian ini adalah analisis Spatial Autoregressive, dengan tahapan analisisnya adalah:

1. Melakukan eksplorasi data dengan menggunakan peta tematik untuk mengetahui penyebaran dari masing-masing variabel dari sudut kewilayahan.

2. Melakukan estimasi parameter dan melakukan pemodelan regresi linear dengan metode OLS.

$$
Y_{i}=\beta_{0}+\beta_{1} X_{i 1}+\cdots+\beta_{p-1} X_{i, p-1}+\varepsilon_{i} .
$$

3. Melakukan uji asumsi pada model regresi linear yang diperoleh menggunakan metode OLS. Uji asumsi yang dilakukan, yaitu uji normalitas, uji non-multikolinearitas, uji nonheteroskedastisitas, dan uji non-autokorelasi. Apabila uji normalitas, uji nonmultikolinearitas, uji non-heteroskedastisitas, dan uji non-autokorelasi terpenuhi maka berhenti pada langkah 2, sehingga model yang dihasilkan menggunakan metode OLS sudah baik. Apabila terdapat pelanggaran pada asumsi non-heteroskedastisitas atau non-autokorelasi, maka model yang dihasilkan menggunakan metode OLS kurang baik dan ada kemungkinan terdapat efek spasial pada data, sehingga dilanjutkan dengan analisis spasial pada langkah 4 .

4. Menentukan matriks pembobot spasial (W) dengan menggunakan metode persinggungan Queen contiguity.

Matriks W diperoleh dari informasi jarak ketetanggaan atau jarak antara lokasi yang satu dengan lokasi lainnya. Bentuk umum matriks pembobot spasial adalah:

$$
W_{i j}=\left[\begin{array}{cccc}
W_{11} & W_{12} & \cdots & W_{1 n} \\
W_{21} & W_{22} & \cdots & W_{2 n} \\
\vdots & \vdots & \ddots & \vdots \\
W_{n 1} & W_{n 2} & \cdots & W_{n n}
\end{array}\right]
$$

Dalam membuat suatu matriks pembobot spasial, ketetanggaan suatu daerah ditandai dengan nilai 0 dan 1 . Elemen $W_{i j}$ bernilai 1 diberikan apabila daerah $i$ dan daerah $j$ memiliki hubungan ketetanggaan, sedangkan $W_{i j}$ bernilai 0 diberikan apabila daerah $i$ dan daerah $j$ tidak memiliki hubungan ketetanggaan.

Untuk membentuk matriks pembobot spasial pada spasial lag atau kombinasi linear dari nilai ketetanggaan suatu wilayah, dapat dilakukan dengan menormalkan matriks ketetanggaan. Normalisasi matriks adalah matriks non-negatif yang mempunyai jumlah baris sama dengan satu (LeSage and Pace, 
2009).

5. Melakukan uji Lagrange Multiplier (LM) untuk melihat adanya kebergantungan spasial pada lag yang menunjukkan model SAR cocok digunakan. Hipotesis untuk pengujian LM lag adalah:

$H_{0}: \rho=0$ (tidak ada kebergantungan spasial),

$H_{1}: \rho \neq 0$ (ada kebergantungan spasial).

Statistik uji untuk LM lag adalah (Fischer and Wang, 2011):

$L M_{\text {lag }}=\left(\frac{\mathbf{e}^{\mathbf{T}} \mathbf{W} \mathbf{y}}{\frac{1}{n}\left(\mathbf{e}^{\mathbf{T}} \mathbf{e}\right)}\right)^{2} \frac{1}{M+N^{\prime}}$

dengan

$M=\left\{(\mathbf{W X} \widehat{\mathbf{\beta}})^{\mathbf{T}}\left[\mathbf{I}-\mathbf{X}\left(\mathbf{X}^{\mathbf{T}} \mathbf{X}\right)^{-\mathbf{1}} \mathbf{X}^{\mathbf{T}}\right]\right.$

$\left.(\mathbf{W X} \widehat{\boldsymbol{\beta}}) \widehat{\boldsymbol{\sigma}}^{-2}\right\}$,

$$
N=\operatorname{tr}\left(\mathbf{W}^{\mathbf{T}} \mathbf{W}+\mathbf{W}^{2}\right) \text {, }
$$

$n$ adalah jumlah amatan.

Kriteria keputusannya adalah tolak $H_{0}$ apabila $p_{\text {value }}<\alpha$ yang berarti model yang sesuai untuk digunakan adalah model SAR.

6. Melakukan pemodelan Spatial Autoregressive (SAR) dengan langkahlangkah:

a. Melakukan pendugaan parameter Spatial Autoregressive (SAR).

Estimasi parameter pada model dilakukan dengan menggunakan metode maksimum likelihood, yaitu dengan membentuk fungsi likelihood. Pembentukan fungsi likelihood dilakukan berdasarkan persamaan (2), yaitu melalui galat $(\varepsilon)$. Sehingga diperoleh fungsi likelihood sebagai

$$
\begin{aligned}
& L\left(\varepsilon ; \sigma^{2}\right)=\left(\frac{1}{2 \pi \sigma^{2}}\right)^{n / 2} \times \\
& \exp \left[-\frac{1}{2 \sigma^{2}}\left(\boldsymbol{\varepsilon}^{\mathbf{T}} \boldsymbol{\varepsilon}\right)\right] .
\end{aligned}
$$

Berdasarkan persamaan (7), fungsi likelihood $L$ dapat dinyatakan sebagai fungsi dari $\rho, \beta$, dan $\sigma^{2}$ yaitu

$$
\begin{aligned}
& L\left(\rho, \beta, \sigma^{2} \mid y\right)=\left(\frac{1}{2 \pi \sigma^{2}}\right)^{n / 2} \times \\
& \left|\mathbf{I}-\boldsymbol{\rho} \mathbf{W}_{\mathbf{1}}\right| \exp \left[-\frac{1}{2 \sigma^{2}}\left(\boldsymbol{\varepsilon}^{\mathbf{T}} \boldsymbol{\varepsilon}\right)\right]
\end{aligned}
$$

dengan

$$
\varepsilon=\left(I-\rho W_{1}\right) \mathbf{y}-\mathbf{X} \boldsymbol{\beta} \text {. }
$$

Selanjutnya dilakukan operasi logaritma natural (ln) likelihood, diperoleh

$$
\ln (L)=-\frac{n}{2} \ln (2 \pi)-\frac{n}{2} \ln \left(\sigma^{2}\right)+
$$

$$
\ln \left|\mathbf{I}-\boldsymbol{\rho} \mathbf{W}_{\mathbf{1}}\right|-\frac{1}{2 \sigma^{2}}\left(\boldsymbol{\varepsilon}^{\mathbf{T}} \boldsymbol{\varepsilon}\right)
$$

dengan

$\boldsymbol{\varepsilon}=\left(\mathbf{I}-\boldsymbol{\rho} \mathbf{W}_{\mathbf{1}}\right) \mathbf{y}-\mathbf{X} \boldsymbol{\beta}$.

Penduga parameter $\beta$ pada model SAR diperoleh dengan memaksimumkan fungsi ln likelihood pada persamaan (9), diperoleh

$$
\begin{aligned}
& \widehat{\boldsymbol{\beta}}=\left(\mathbf{X}^{\mathrm{T}} \mathbf{X}\right)^{-\mathbf{1}} \mathbf{X}^{\mathrm{T}} \mathbf{y}-\left(\mathbf{X}^{\mathrm{T}} \mathbf{X}\right)^{-\mathbf{1}} \\
& \mathbf{X}^{\mathrm{T}} \rho \mathbf{W}_{\mathbf{1}} \mathbf{y} .
\end{aligned}
$$

Penduga parameter $\sigma^{2}$ diperoleh dengan cara memaksimumkan fungsi ln likelihood pada persamaan (9), diperoleh

$$
\begin{aligned}
& \hat{\sigma}^{2} \\
& =\frac{\left(\mathbf{e}_{\mathbf{o}}-\rho \mathbf{e}_{\mathbf{n}}\right)^{\mathbf{T}}\left(\mathbf{e}_{\mathbf{o}}-\rho \mathbf{e}_{\mathbf{n}}\right)}{n} \text {. }
\end{aligned}
$$

Substitusi $\hat{\sigma}^{2}$ pada persamaan (9), dan untuk menduga parameter $\rho$ dilakukan menggunakan fungsi logaritma natural, diperoleh

$$
\begin{aligned}
& \ln (L(\rho))=-\frac{n}{2} \ln (2 \pi)- \\
& \frac{n}{2} \ln \left(\mathbf{e}^{\mathbf{T}} \mathbf{e}\right)+\frac{n}{2} \ln (n)+ \\
& \ln \left|\mathbf{I}-\rho \mathbf{W}_{\mathbf{1}}\right|-\frac{n}{2}
\end{aligned}
$$

dengan

$\mathbf{e}=\mathbf{e}_{\mathbf{o}}-\rho \mathbf{e}_{\mathbf{n}}$.

Penduga parameter $\rho$ diperoleh dengan memaksimumkan persamaan (12). Penduga parameter $\rho$ tidak didapat secara langsung, namun dapat menggunakan teknik numerik dalam memaksimumkan persamaan (12).

b. Melakukan pengujian signifikansi parameter dengan menggunakan uji Wald. Hipotesis untuk uji Wald adalah

$H_{0}: \rho, \beta_{j}=0 \quad$ (parameter signifikan), dengan $j=1, \ldots, p-1$,

$H_{1}: \rho, \beta_{j} \neq 0$ (parameter tidak signifikan), dengan $j=1, \ldots, p-1$.

Dengan $p-1$ adalah jumlah variabel bebas.

Statistik uji yang digunakan adalah (Anselin, 1988),

dengan

$$
W=\left(\frac{r}{s e(r)}\right)
$$

$r$ adalah nilai penduga suatu parameter, $s e(r)$ adalah standar deviasi dari penduga parameter $r$.

Kriteria keputusannya adalah tolak $H_{0}$ apabila $W>Z_{\frac{\alpha}{2}}$ atau $p-$ value $<\alpha$. 
c. Melakukan uji Breusch-Pagan untuk mengetahui ada tidaknya heteroskedastisitas pada model SAR.

d. Menginterpretasi dan membuat kesimpulan.

\section{HASIL DAN PEMBAHASAN}

\subsection{Deskripsi Kabupaten/Kota di Provinsi Jawa Timur Berdasarkan Jumlah Kasus Penyakit Kusta serta Faktor-faktor yang Memengaruhinya}

Pada penelitian ini angka yang menunjukkan banyaknya kasus dari setiap variabel digambar-kan dalam sebuah peta tematik, yang bertujuan untuk mengetahui penyebaran setiap variabel dari sudut kewilayahan. Peta tematik merupakan peta khusus yang menyajikan tema tertentu yang berfungsi untuk menambah informasi, sehingga memudahkan pembaca dalam membaca peta serta memahami informasi mengenai variabelvariabel yang digunakan. Setiap variabel dikelompokkan menjadi lima kategori yaitu kategori sangat rendah, rendah, sedang, tinggi, dan sangat tinggi. Dalam memudahkan membaca peta tematik, maka hasil dari penggambaran peta tematik akan disajikan dalam bentuk tabel distribusi. Berikut merupakan tabel distribusi pengelompokan untuk setiap variabel.

1. Variabel $Y$

Tabel 1. Pengelompokan Jumlah Kasus Penyakit Kusta

\begin{tabular}{|c|l|}
\hline Kategori & \multicolumn{1}{|c|}{ Kabupaten } \\
\hline Sangat \\
Rendah & $\begin{array}{l}\text { Kota Batu, Kab. Pacitan, Kota } \\
\text { Blitar, Kota Madiun, Kota Kediri, } \\
\text { Kota Mojokerto, Kab. Trenggalek, } \\
\text { Kota Pasuruan }\end{array}$ \\
\hline Rendah & $\begin{array}{l}\text { Kab. Blitar, Kota Probolinggo, Kab. } \\
\text { Kediri, Kab. Madiun, Kota Malang, } \\
\text { Kab. Tulungagung, Kab. Ponorogo, } \\
\text { Kab. Mojokerto, Kab. Ngawi, Kab. } \\
\text { Magetan }\end{array}$ \\
\hline Sedang & $\begin{array}{l}\text { Kab. Banyuwangi, Kab. } \\
\text { Bondowoso, Kab. Malang, Kab. } \\
\text { Lamongan, Kab. Sidoarjo, Kab. } \\
\text { Nganjuk, Kab. Bojonegoro, Kab. } \\
\text { Jombang, Kab. Gresik }\end{array}$ \\
\hline Sangat & $\begin{array}{l}\text { Kab. Situbondo, Kab. Probolinggo, } \\
\text { Kota Surabaya, Kab. Lumajang, } \\
\text { Kab. Tuban, Kab. Pasuruan }\end{array}$ \\
\hline Tinggi & $\begin{array}{l}\text { Kab. Bangkalan, Kab. Jember, Kab. } \\
\text { Pamekasan, Kab. Sampang, Kab. } \\
\text { Sumenep }\end{array}$ \\
\hline
\end{tabular}

\section{Variabel $X_{1}$}

Tabel 2. Pengelompokan Kepadatan Penduduk

\begin{tabular}{|c|l|}
\hline Kategori & \multicolumn{1}{|c|}{ Kabupaten } \\
Sangat & Kab. Banyuwangi, Kab. Pacitan, \\
Rendah & Kab. Situbondo, Kab. Bondowoso, \\
& Kab. Sumenep, Kab. Bojonegoro, \\
& Kab. Trenggalek, Kab. Lumajang \\
\hline \multirow{5}{*}{ Rendah } & Kab. Ponorogo, Kab. Tuban, Kab. \\
& $\begin{array}{l}\text { Ngawi, Kab. Lamongan, Kab. } \\
\text { Madiun, Kab. Probolinggo, Kab. } \\
\text { Blitar, Kab. Jember, Kab. } \\
\text { Bangkalan, Kab. Sampang, Kab. } \\
\\
\text { Malang, Kab. Nganjuk, Kab. } \\
\text { Tulungagung, Kab. Magetan }\end{array}$ \\
\hline Sedang & $\begin{array}{l}\text { Kota Batu, Kab. Gresik, Kab. } \\
\text { Jombang, Kab. Pamekasan, Kab. } \\
\text { Pasuruan, Kab. Kediri, Kab. } \\
\text { Mojokerto }\end{array}$ \\
\hline \multirow{2}{*}{ Tinggi } & $\begin{array}{l}\text { Kab. Sidoarjo, Kota Probolinggo, } \\
\text { Kota Kediri, Kota Blitar, Kota } \\
\text { Madiun, Kota Pasuruan }\end{array}$ \\
\hline Sangat \\
Tinggi & $\begin{array}{l}\text { Kota Mojokerto, Kota Malang, Kota } \\
\text { Surabaya }\end{array}$ \\
\hline
\end{tabular}

\section{Variabel $X_{2}$}

Tabel 3. Pengelompokkan Persentase Rumah Tangga BerPHBS

\begin{tabular}{|c|c|}
\hline Kategori & Kabupaten \\
\hline $\begin{array}{l}\text { Sangat } \\
\text { Rendah }\end{array}$ & $\begin{array}{l}\text { Kab. Probolinggo, Kab. Situbondo, } \\
\text { Kab. Lumajang, Kab. Bondowoso, } \\
\text { Kota Batu }\end{array}$ \\
\hline Rendah & $\begin{array}{l}\text { Kab. Trenggalek, Kota Malang, } \\
\text { Kab. Tulungagung, Kota Blitar, } \\
\text { Kab. Pacitan, Kab. Banyungawi, } \\
\text { Kab. Magetan, Kab. Nganjuk, Kab. } \\
\text { Pasuruan, Kab. Blitar }\end{array}$ \\
\hline Sedang & $\begin{array}{l}\text { Kab. Madiun, Kota Pasuruan, Kota } \\
\text { Kediri, Kab. Malang, Kab. } \\
\text { Mojokerto, Kab. Kediri, Kab. } \\
\text { Bojonegoro, Kab. Pamekasan, Kab. } \\
\text { Sampang, Kab. Sumenep, Kab. } \\
\text { Jombang }\end{array}$ \\
\hline Tinggi & $\begin{array}{l}\text { Kab. Bangkalan, Kota Mojokerto, } \\
\text { Kota Madiun, Kab. Ponorogo, Kab. } \\
\text { Sidoarjo, Kab. Gresik, Kab. Jember, } \\
\text { Kota Probolinggo, Kota Surabaya, } \\
\text { Kab. Lamongan, Kab. Tuban }\end{array}$ \\
\hline $\begin{array}{l}\text { Sangat } \\
\text { Tinggi }\end{array}$ & Kab. Ngawi \\
\hline
\end{tabular}




\section{Variabel $X_{3}$}

Tabel 4. Pengelompokkan Persentase Rumah Sehat

\begin{tabular}{|c|c|}
\hline Kategori & Kabupaten \\
\hline $\begin{array}{l}\text { Sangat } \\
\text { Rendah }\end{array}$ & $\begin{array}{l}\text { Kab. Sampang, Kab. Probolinggo, } \\
\text { Kab. Situbondo, Kab. Sumenep, } \\
\text { Kab. Pamekasan }\end{array}$ \\
\hline Rendah & $\begin{array}{l}\text { Kab. Ngawi, Kab. Pasuruan, Kab. } \\
\text { Nganjuk, Kab. Bondowoso, Kab. } \\
\text { Jember }\end{array}$ \\
\hline Sedang & $\begin{array}{l}\text { Kab. Mojokerto, Kab. Tuban, Kab. } \\
\text { Blitar, Kab. Bojonegoro, Kab. } \\
\text { Kediri, Kab. Magetan, Kab. } \\
\text { Jombang, Kab. Malang, Kab. } \\
\text { Pacitan, Kab. Tulungagung, Kab. } \\
\text { Banyuwangi }\end{array}$ \\
\hline Tinggi & $\begin{array}{l}\text { Kab. Madiun, Kab. Ponorogo, Kota } \\
\text { Blitar, Kab. Bangkalan, Kota } \\
\text { Mojokerto, Kota Malang, Kab. } \\
\text { Trenggalek, Kab. Sidoarjo, Kota } \\
\text { Pasuruan, Kota Probolinggo, Kota } \\
\text { Kediri }\end{array}$ \\
\hline $\begin{array}{l}\text { Sangat } \\
\text { Tinggi }\end{array}$ & $\begin{array}{l}\text { Kota Madiun, Kab. Gresik, Kota } \\
\text { Surabaya, Kab. Lumajang, Kab. } \\
\text { Lamongan, Kota Batu }\end{array}$ \\
\hline
\end{tabular}

5. Variabel $X_{4}$

Tabel 5. Pengelompokkan Persentase Penduduk Miskin

\begin{tabular}{|c|c|}
\hline Kategori & Kabupaten \\
\hline $\begin{array}{l}\text { Sangat } \\
\text { Rendah }\end{array}$ & $\begin{array}{l}\text { Kota Malang, Kota Batu, Kota } \\
\text { Madiun, Kota Surabaya, Kota } \\
\text { Mojokerto, Kab. Sidoarjo }\end{array}$ \\
\hline Rendah & $\begin{array}{l}\text { Kota Pasuruan, Kota Probolinggo, } \\
\text { Kota Blitar, Kab. Tulungagung, Kota } \\
\text { Kediri, Kab. Banyuwangi, Kab. } \\
\text { Blitar }\end{array}$ \\
\hline Sedang & $\begin{array}{l}\text { Kab. Mojokerto, Kab. Pasuruan, } \\
\text { Kab. Jombang, Kab. Magetan, Kab. } \\
\text { Lumajang, Kab. Jember, Kab. } \\
\text { Malang, Kab. Ponorogo, Kab. } \\
\text { Nganjuk, Kab. Kediri, Kab. Madiun, } \\
\text { Kab. Gresik, Kab. Trenggalek, Kab. } \\
\text { Situbondo }\end{array}$ \\
\hline Tinggi & $\begin{array}{l}\text { Kab. Bojonegoro, Kab. Lamongan, } \\
\text { Kab. Bondowoso, Kab. Ngawi, Kab. } \\
\text { Pacitan, Kab. Pamekasan, Kab. } \\
\text { Tuban }\end{array}$ \\
\hline $\begin{array}{l}\text { Sangat } \\
\text { Tinggi }\end{array}$ & $\begin{array}{l}\text { Kab. Sumenep, Kab. Probolinggo, } \\
\text { Kab. Bangkalan, Kab. Sampang }\end{array}$ \\
\hline
\end{tabular}

6. Variabel $X_{5}$

Tabel 6. Pengelompokkan Persentase Penduduk dengan Pendidikan Terakhir SD

\begin{tabular}{|c|c|}
\hline Kategori & Kabupaten \\
\hline $\begin{array}{l}\text { Sangat } \\
\text { Rendah }\end{array}$ & $\begin{array}{l}\text { Kota Madiun, Kota Mojokerto, } \\
\text { Kota Malang, Kab. Sidoarjo, Kota } \\
\text { Surabaya }\end{array}$ \\
\hline Rendah & $\begin{array}{l}\text { Kota Kediri, Kota Blitar, Kota Batu, } \\
\text { Kota Probolinggo, Kab. Gresik, } \\
\text { Kab. Mojokerto, Kota Pasuruan }\end{array}$ \\
\hline Sedang & $\begin{array}{l}\text { Kab. Lamongan, Kab. Sumenep, } \\
\text { Kab. Ponorogo, Kab. Magetan, } \\
\text { Kab. Madiun, Kab. Pamekasan, } \\
\text { Kab. Bondowoso, Kab. Jombang, } \\
\text { Kab. Ngawi, Kab. Blitar }\end{array}$ \\
\hline Tinggi & $\begin{array}{l}\text { Kab. Banyuwangi, Kab. Kediri, } \\
\text { Kab. Situbondo, Kab. Sampang, } \\
\text { Kab. Nganjuk, Kab. Jember, Kab. } \\
\text { Bojonegoro }\end{array}$ \\
\hline $\begin{array}{l}\text { Sangat } \\
\text { Tinggi }\end{array}$ & $\begin{array}{l}\text { Kab. Pasuruan, Kab. Probolinggo, } \\
\text { Kab. Tuban, Kab. Malang, Kab. } \\
\text { Tulungagung, Kab. Pacitan, Kab. } \\
\text { Trenggalek, Kab. Bangkalan, Kab. } \\
\text { Lumajang }\end{array}$ \\
\hline
\end{tabular}

\section{Variabel $X_{6}$}

Tabel 7. Pengelompokkan Jumlah Puskesmas

\begin{tabular}{|c|l|}
\hline Kategori & \multicolumn{1}{|c|}{ Kabupaten } \\
\hline \multirow{3}{*}{ Sangat } & $\begin{array}{l}\text { Kota Blitar, Kota Mojokerto, Kota } \\
\text { Batu, Kota Probolinggo, Kota } \\
\text { Madiun, Kota Pasuruan, Kota } \\
\text { Kediri }\end{array}$ \\
\hline \multirow{5}{*}{ Rendah } & $\begin{array}{l}\text { Kota Malang, Kab. Situbondo, Kab. } \\
\text { Nganjuk, Kab. Pamekasan, Kab. } \\
\text { Sampang, Kab. Trenggalek, Kab. } \\
\\
\text { Magetan, Kab. Bangkalan }\end{array}$ \\
\hline \multirow{5}{*}{ Tinggi } & $\begin{array}{l}\text { Kab. Pacitan, Kab. Blitar, Kab. } \\
\text { Ngawi, Kab. Lumajang, Kab. } \\
\text { Bondowoso, Kab. Sidoarjo, Kab. } \\
\text { Madiun, Kab. Mojokerto }\end{array}$ \\
& $\begin{array}{l}\text { Kab. Sumenep, Kab. Ponorogo, } \\
\text { Kab. Tulungagung, Kab. Gresik, } \\
\text { Kab. Probolinggo, Kab. Pasuruan, } \\
\text { Kab. Tuban, Kab. Lamongan, Kab. } \\
\text { Jombang, Kab. Bojonegoro, Kab. } \\
\text { Kediri, Kab. Malang }\end{array}$ \\
\hline Sangat \\
Tinggi & $\begin{array}{l}\text { Kab. Banyuwangi, Kab. Jember dan } \\
\text { Kota Surabaya }\end{array}$ \\
\hline
\end{tabular}




\subsection{Estimasi Model Regresi Linier dan Uji Asumsi Analisis Regresi Linear}

Estimasi parameter model regresi linear pada penelitian ini adalah:

Tabel 8. Estimasi Parameter Model Regresi Linear

\begin{tabular}{|l|r|r|r|}
\hline \multicolumn{1}{|c|}{ Variabel } & Estimasi & $t_{\text {hitung }}$ & $P_{\text {value }}$ \\
\hline \multicolumn{1}{|c|}{ Konstanta } & 1,109 & 0,007 & 0,994 \\
\hline $\begin{array}{l}\text { Kepadatan } \\
\text { Penduduk }\left(X_{1}\right)\end{array}$ & 0,011 & 1,194 & 0,242 \\
\hline $\begin{array}{l}\text { Rumah Tangga } \\
\text { Ber-PHBS }\left(X_{2}\right)\end{array}$ & 0,289 & 0,274 & 0,786 \\
\hline $\begin{array}{l}\text { Rumah Sehat } \\
\left(X_{3}\right)\end{array}$ & $-1,933$ & $-1,698$ & 0,099 \\
\hline $\begin{array}{l}\text { Penduduk Miskin } \\
\left(X_{4}\right)\end{array}$ & 11,683 & 2,308 & $0,028^{*}$ \\
\hline $\begin{array}{l}\text { Pendidikan } \\
\text { Terakhir SD }\left(X_{5}\right)\end{array}$ & 0,024 & 0,007 & 0,994 \\
\hline Puskesmas $\left(X_{6}\right)$ & 2,191 & 1,821 & 0,078 \\
\hline
\end{tabular}

Sumber: Data diolah, 2019

Dengan $\alpha=0,05$ dan $R_{a}^{2}=42,948 \%$

Berdasarkan Tabel 8, estimasi model regresi linear yang diperoleh adalah

$\hat{Y}_{i}=1,109+0,011 X_{1, i}+0,289 X_{2, i}$

$-1,933 X_{3, i}+11,683 X_{4, i}+0,024 X_{5, i}$

$+2,191 X_{6, i}$

Pengujian asumsi analisis regresi linear pada persamaan (14) adalah:

1. Uji Normalitas

Uji normalitas yang digunakan adalah uji Anderson-Darling dengan hipotesis:

$H_{0}$ : data residual mengikuti distribusi normal,

$H_{1}$ : data residual tidak mengikuti distribusi normal.

Diperoleh hasil nilai $A D=0,907$ dan $p_{\text {value }}=0,019$. Dari hasil tersebut diperoleh bahwa $p_{\text {value }}<\alpha=0,05$ sehingga keputusannya tolak $H_{0}$ yang berarti data residual tidak berdistribusi normal.

2. Uji Autokorelasi

Uji autokorelasi yang digunakan adalah uji Durbin-Watson dengan hipotesis:

$H_{0}$ : tidak terdapat autokorelasi,

$H_{1}$ : terdapat autokorelasi.

Diperoleh hasil nilai Durbin-Watson adalah 1,473. Nilai tersebut berada diantara nilai $d L=1,1463$ dan $d U=1,8641$, sehingga keputusannya tidak dapat menolak atau menerima $H_{0}$ yang berarti bahwa tidak dapat disimpulkan ada tidaknya autokorelasi.
3. Uji Heteroskedastisitas

Uji heteroskedastisitas yang digunakan adalah uji Breusch-Pagan dengan hipotesis:

$H_{0}$ : tidak ada gejala heteroskedastisitas,

$H_{1}$ : ada gejala heteroskedastisitas.

Diperoleh hasil nilai $B P=8,4672$ dan $p_{\text {value }}=0,20584$. Dari hasil tersebut diperoleh bahwa $p_{\text {value }}>\alpha=0,05$ sehingga keputusannya terima $H_{0}$ yang berarti tidak ada gejala heteroskedastisitas.

4. Uji Multikolinieritas

Diperoleh hasil nilai VIF masing-masing variabel bebas $\mathrm{X}$, yaitu $X_{1}=2,437 ; X_{2}=$ 1,$425 ; \quad X_{3}=1,933 ; \quad X_{4}=3,165 ; \quad X_{5}=$ 3,$095 ; X_{6}=1,349$. Berdasarkan hasil tersebut diperoleh bahwa nilai $V I F<5$ sehingga dapat disimpulkan tidak terjadi multi-kolinieritas.

Berdasarkan hasil uji asumsi tersebut diperoleh keputusan uji normalitas AndersonDarling adalah $H_{0}$ ditolak yang berarti sisaan tidak mengikuti sebaran normal. Untuk pengujian pencilan diperoleh hasil bahwa tidak terdapat pencilan pada data. Salah satu cara yang dapat dilakukan untuk mengatasi pelanggaran asumsi normalitas adalah dilakukan transformasi pada data. Transformasi data yang akan digunakan dapat ditentukan dengan melihat nilai $\lambda$ pada model regresi Box-Cox. Diperoleh estimasi parameter $\lambda$ untuk data jumlah kasus penyakit kusta di Provinsi Jawa Timur adalah 0,21 . Hasil estimasi tersebut mendekati nilai nol, sehingga data jumlah kasus penyakit kusta $(Y)$ akan ditransformasi dalam bentuk logaritma natural (ln). Tabel 2 menunjukkan hasil estimasi parameter regresi pada data yang telah ditransformasi.

Tabel 9. Estimasi Parameter Model Regresi Linear Setelah Ditransformasi

\begin{tabular}{|l|r|r|r|}
\hline \multicolumn{1}{|c|}{ Variabel } & $\begin{array}{r}\text { Estimasi } \\
\text { Parameter }\end{array}$ & $t_{\text {hitung }}$ & $P_{\text {value }}$ \\
\hline \multicolumn{1}{|c|}{ Konstanta } & 2,293 & 1,089 & 0,285 \\
\hline $\begin{array}{l}\text { Kepadatan } \\
\text { Penduduk }\left(X_{1}\right)\end{array}$ & $\begin{array}{r}6,174 \times \\
10^{-5}\end{array}$ & 0,488 & 0,629 \\
\hline $\begin{array}{l}\text { Rumah Tangga } \\
\text { Ber-PHBS }\left(X_{2}\right)\end{array}$ & 0,007 & 0,476 & 0,638 \\
\hline $\begin{array}{l}\text { Rumah Sehat } \\
\left(X_{3}\right)\end{array}$ & $-0,032$ & $-2,014$ & 0,053 \\
\hline $\begin{array}{l}\text { Penduduk } \\
\text { Miskin }\left(X_{4}\right)\end{array}$ & 0,093 & 1,301 & 0,203 \\
\hline $\begin{array}{l}\text { Pendidikan } \\
\text { Terakhir SD }\left(X_{5}\right)\end{array}$ & 0,013 & 0,278 & 0,783 \\
\hline Puskesmas $\left(X_{6}\right)$ & 0,065 & 3,85 & $\begin{array}{c}5,5 \times \\
10^{-4}\end{array}$ \\
\hline
\end{tabular}

Sumber: Data diolah, 2019 
Dengan $\alpha=0,05$ dan $R_{a}^{2}=53,761 \%$

Estimasi model regresi linear pada data yang telah ditransformasi berdasarkan Tabel 9 adalah $\ln \hat{Y}_{i}=2,293+6,174 \times 10^{-5} X_{1, i}+$ $0,007 X_{2, i}-0,032 X_{3, i}+0,093 X_{4, i}+$

$0,013 X_{5, i}+0,065 X_{6, i}$

Pengujian asumsi analisis regresi linear pada persamaan (15) adalah:

1. Uji Normalitas

Diperoleh hasil nilai $A D=0,610$ dan $p_{\text {value }}=0,105$. Dari hasil tersebut diperoleh bahwa $\quad p_{\text {value }}>\alpha=0,05 \quad$ sehingga keputusannya terima $H_{0}$ yang berarti data residual berdistribusi normal.

2. Uji Autokorelasi

Diperoleh hasil nilai Durbin-Watson adalah 1,462. Nilai tersebut berada diantara nilai $d L=1,1463$ dan $d U=1,8641$, sehingga diperoleh keputusan tidak dapat menolak atau menerima $H_{0}$ yang berarti bahwa tidak dapat disimpulkan ada tidaknya autokorelasi.

3. Uji Heteroskedastisitas

Diperoleh hasil nilai $B P=16,2556$ dan $p_{\text {value }}=0,01245$. Dari hasil tersebut diperoleh bahwa $p_{\text {value }}<\alpha=0,05$ sehingga keputusannya tolak $H_{0}$ yang berarti terdapat gejala heteroskedastisitas.

4. Uji Multikolinieritas

Diperoleh hasil nilai VIF masing-masing variabel bebas $\mathrm{X}$, yaitu $X_{1}=2,437 ; X_{2}=$ 1,$425 ; \quad X_{3}=1,933 ; \quad X_{4}=3,165 ; \quad X_{5}=$ 3,$095 ; X_{6}=1,349$. Berdasarkan hasil tersebut diperoleh bahwa nilai $V I F<5$ sehingga dapat disimpulkan tidak terjadi multi-kolinieritas.

Berdasarkan hasil tersebut terlihat bahwa masih terdapat pelanggaran asumsi dari uji asumsi model regresi yang telah ditransformasi. Pelanggaran asumsi tersebut, yaitu pada uji nonheteroskedastisitas diperoleh hasil terdapat gejala heteroskedastisitas dan pada uji nonautokorelasi diperoleh hasil tidak dapat disimpulkan ada autokorelasi atau tidak, sehingga model regresi linear pada persamaan (14) kurang baik untuk digunakan. Oleh karena itu diduga terdapat efek spasial pada data, sehingga analisis dilanjutkan dengan pengujian kebergantungan spasial untuk melihat ada tidaknya pengaruh spasial pada data yang digunakan.

\subsection{Pengujian Kebergantungan Spasial}

Pengujian efek spasial akan diselidiki meng-gunakan Uji Lagrange Multiplier.
Hipotesis dari uji Lagrange Multiplier (LM) untuk model SAR yaitu:

$H_{0}: \rho=0$ (tidak ada kebergantungan spasial),

$H_{1}: \rho \neq 0$ (ada kebergantungan spasial ).

Diperoleh nilai Lagrange Multiplier (lag) yaitu 7,615 , dengan nilai probabilitas atau $p_{\text {value }}$ yaitu 0,006 yang lebih kecil dari $\alpha=0,05$ sehingga keputusannya adalah tolak $H_{0}$ yang berarti terdapat kebergantungan spasial pada variabel respons. Dengan kata lain kabupaten/kota di Provinsi Jawa Timur saling bergantung satu sama lain. Karena LM (lag) signifikan, maka model yang sesuai untuk digunakan dalam kasus penyakit kusta di Provinsi Jawa Timur adalah model Spatial Autoregressive (SAR). Sehingga akan dilakukan pemodelan berdasarkan metode spasial, yaitu pemodelan Spatial Autoregressive (SAR).

\subsection{Pemodelan SAR}

Pemodelan SAR dilakukan dengan menguji signifikansi parameter terlebih dahulu menggunakan Uji Wald.

Hipotesis yang digunakan dalam uji Wald adalah:

$H_{0}: \rho, \beta_{j}=0$ (parameter signifikan), dengan $j=1, \ldots, p-1$,

$H_{1}: \rho, \beta_{j} \neq 0$ (parameter tidak signifikan), dengan $j=1, \ldots, p-1$.

Tabel 10. Pendugaan Parameter SAR

\begin{tabular}{|l|r|c|c|}
\hline \multicolumn{1}{|c|}{ Variabel } & $\begin{array}{r}\text { Estimasi } \\
\text { Parameter }\end{array}$ & Wald & Prob. \\
\hline \multicolumn{1}{|c|}{$\rho$} & 0,531 & 4,808 & $0,000^{*}$ \\
\hline Konstanta & 0,522 & 0,324 & 0,746 \\
\hline $\begin{array}{l}\text { Kepadatan } \\
\text { Penduduk }\left(X_{1}\right)\end{array}$ & $\begin{array}{r}1,049 \times \\
10^{-5}\end{array}$ & 0,112 & 0,911 \\
\hline $\begin{array}{l}\text { Rumah Tangga } \\
\text { Ber-PHBS }\left(X_{2}\right)\end{array}$ & 0,009 & 0,781 & 0,435 \\
\hline $\begin{array}{l}\text { Rumah Sehat } \\
\left(X_{3}\right)\end{array}$ & $-0,032$ & $-2,66$ & $0,008^{*}$ \\
\hline $\begin{array}{l}\text { Penduduk } \\
\text { Miskin }\left(X_{4}\right)\end{array}$ & 0,023 & 0,426 & 0,671 \\
\hline $\begin{array}{l}\text { Pendidikan } \\
\text { Terakhir SD } \\
\left(X_{5}\right)\end{array}$ & 0,031 & 0,903 & 0,367 \\
\hline Puskesmas $\left(X_{6}\right)$ & 0,061 & 4,874 & $0,000^{*}$ \\
\hline
\end{tabular}

Sumber: Data diolah, 2019

Dengan $\alpha=0,05, R^{2}=73,792 \%$, dan

$A I C=115,264$.

Berdasarkan Tabel 10 diperoleh model umum SAR dengan semua variabel bebas, yaitu: $\ln \hat{y}_{i}=0,531 \mathbf{W} \ln y_{j}+0,522+1,0 \times 10^{-5} X_{1 i}$ $+0,009 X_{2 i}-0,032 X_{3 i}+0,023 X_{4 i}+0,031 X_{5 i}$ 
$+0,061 X_{6 i}$

atau

$\hat{y}_{i}=\exp \left(0,531 \mathbf{W} \ln y_{j}+0,522\right.$

$+1,049 \times 10^{-5} X_{1 i}+0,009 X_{2 i}-$

$0,032 X_{3 i}+0,023 X_{4 i}+0,031 X_{5 i}+$

$\left.0,061 X_{6 i}\right)$.

Selanjutnya akan dimodelkan kembali Spatial Autoregressive menggunakan variabelvariabel yang berpengaruh signifikan terhadap jumlah kasus penyakit kusta di Provinsi Jawa Timur tahun 2017. Diperoleh estimasi parameter SAR dengan variabel-variabel yang signifikan yang ditunjukkan pada Tabel 11.

Tabel 11. Pendugaan Parameter SAR dengan Variabel $X_{3}$ dan $X_{6}$

\begin{tabular}{|l|r|r|l|}
\hline \multicolumn{1}{|c|}{ Variabel } & $\begin{array}{c}\text { Estimasi } \\
\text { Parameter }\end{array}$ & Wald & Prob. \\
\hline \multicolumn{1}{|c|}{$\rho$} & 0,536 & 5,031 & $0,000^{*}$ \\
\hline Konstanta & 2,423 & 2,662 & $0,008^{*}$ \\
\hline $\begin{array}{l}\text { Rumah Sehat } \\
\left(X_{3}\right)\end{array}$ & $-0,039$ & $-4,286$ & $0,000^{*}$ \\
\hline $\begin{array}{l}\text { Puskesmas } \\
\left(X_{6}\right)\end{array}$ & 0,07 & 6,183 & $0,000^{*}$ \\
\hline
\end{tabular}

Sumber: Data diolah, 2019

Dengan $\alpha=0,05, R^{2}=71,93 \%$, dan $A I C=$ 109,951 .

Berdasarkan Tabel 11 diperoleh model SAR, yaitu:

$\ln \hat{y}_{i}=2,423+0,536 \mathbf{W} \ln y_{j}-0,039 X_{3 i}$ $+0,07 X_{6 i}$

atau

$\hat{y}_{i}=\exp \left(2,423+0,536 \mathbf{W} \ln y_{j}\right.$

$\left.-0,039 X_{3 i}+0,07 X_{6 i}\right)$.

dengan $y_{i}$ menyatakan jumlah kasus penyakit kusta pada kabupaten ke-i, $y_{j}$ menyatakan jumlah kasus penyakit kusta pada kabupaten ke$\mathrm{j}$, W menyatakan matriks pembobot spasial (Queen contiguity), $X_{3 i}$ menyatakan persentase rumah sehat pada kabupaten ke-i, $X_{6 i}$ menyatakan jumlah puskesmas pada kabupaten ke-i.

Selanjutkan dilakukan uji heteroskedastisitas pada model SAR untuk variabel yang signifikan, yaitu variabel $X_{3}$ dan $X_{6}$. Uji yang digunakan untuk mengetahui keragaman spasial pada model SAR untuk variabel yang signifikan adalah menggunakan Uji BreuschPagan.

Diperoleh nilai Breusch-Pagan adalah 1,771 , dengan nilai probabilitas atau $p_{\text {value }}$ adalah 0,413 lebih besar dari $\alpha=0,05$ sehingga keputusannya terima $H_{0}$ yang berarti tidak terdapat heteroskedastisitas pada model SAR.

\subsection{Interpretasi}

Model SAR pada persamaan (17) dapat diinterpretasikan sebagai:

1. Koefisien $\rho=\exp (0,536)=1,709$, dan $\rho$ bernilai positif, yang berarti bahwa besarnya interaksi spasial antarkabupaten/kota di Provinsi Jawa Timur yang memiliki karakteristik yang sama adalah sebesar 1,709.

2. Koefisien $\hat{\beta}_{0}=\exp (2,423)=11,28$, menginterpretasikan bahwa apabila faktor lain dianggap tidak ada (bernilai nol), maka rata-rata jumlah kasus penyakit kusta di Provinsi Jawa Timur pada tahun 2017 adalah 11,28 kasus.

3. Koefisien $\hat{\beta}_{3}=\exp (-0,039)=0,962$, dengan $\hat{\beta}_{3}$ bernilai negatif dan $\exp \left(\hat{\beta}_{3}\right)<$ 1, menginterpretasikan bahwa jika persentase rumah sehat di suatu kabupaten/kota naik satu persen, maka dapat menurunkan jumlah kasus penyakit kusta di kabupaten/kota tersebut sebesar 0,962 apabila faktor lain dianggap konstan. Hal ini sesuai dengan penelitian yang dilakukan oleh Rismawati (2013) yang menyatakan bahwa sanitasi rumah memiliki pengaruh terhadap perkembangan penyakit kusta. Apabila sanitasi rumah memiliki standar kesehatan yang baik, maka penghuni rumah akan terhindar dari berbagai macam penyakit, salah satunya penyakit kusta.

4. Koefisien $\hat{\beta}_{6}=\exp (0,07)=1,073$, dengan $\hat{\beta}_{6}$ bernilai positif dan $\exp \left(\hat{\beta}_{6}\right)>$ 1 , meng-interpretasikan bahwa jika jumlah puskesmas di suatu kabupaten/kota naik satu satuan, maka dapat meningkatkan jumlah kasus penyakit kusta di kabupaten/kota tersebut sebesar 1,073 apabila faktor lain dianggap konstan. Interpretasi tersebut tidak sesuai berdasarkan teori yang ada. Peningkatan jumlah puskesmas diadakan apabila kepadatan penduduk di suatu kabupaten/kota cukup tinggi, bukan karena adanya peningkatan atau penurunan jumlah penyakit kusta. Sehingga untuk koefisien $\hat{\beta}_{6}$ tidak dapat diinterpretasikan seperti demikian, namun hanya bisa menunjukkan bahwa jumlah puskesmas berpengaruh signifikan terhadap jumlah kasus penyakit kusta. 
Berdasarkan model SAR pada persamaan (16), diketahui bahwa setiap kabupaten/kota akan memiliki model yang berbeda-beda, tergantung pada matriks pembobot spasial dari kabupaten/ kota $\left(W_{1}\right)$. Sebagai contoh model SAR untuk Kabupaten Pacitan yaitu

$\ln \hat{y}_{\text {Pacitan }}=2,423+0,268 \ln y_{\text {Ponorogo }}$ $+0,268 \ln y_{\text {Trenggalek }}-0,039 X_{3, \text { Pacitan }}$ $+0,07 X_{6, \text { Pacitan }}$

atau

$\hat{y}_{\text {Pacitan }}=\exp (2,423+$

$0,268 \ln y_{\text {Ponorogo }}+$

$0,268 \ln y_{\text {Trenggalek }}-$

$\left.0,039 X_{3, \text { Pacitan }}+0,07 X_{6, \text { Pacitan }}\right)$.

\section{KESIMPULAN DAN SARAN}

\subsection{Kesimpulan}

Model SAR yang digunakan untuk memodelkan jumlah kasus penyakit kusta di Provinsi Jawa Timur pada tahun 2017 adalah $\ln \hat{y}_{i}=2,423+0,536 \mathbf{W} \ln y_{j}-0,039 X_{3 i}$ $+0,07 X_{6 i}$ atau

$\hat{y}_{i}=\exp \left(2,423+0,536 \mathbf{W} \ln y_{j}-0,039 X_{3 i}\right.$ $\left.+0,07 X_{6 i}\right)$

dengan nilai AIC sebesar 109,951 dan nilai $\mathrm{R}^{2}$ sebesar $71,93 \%$.

Keterangan: $y_{i}$ menyatakan jumlah kasus penyakit kusta pada kabupaten ke-i, $y_{j}$ menyatakan jumlah kasus penyakit kusta pada kabupaten ke-j, $\mathbf{W}$ menyatakan matriks pembobot spasial (Queen contiguity), $X_{3 i}$ menyatakan persentase rumah sehat pada kabupaten ke-i, $X_{6 i}$ menyatakan jumlah puskesmas pada kabupaten ke-i.

Adapun faktor-faktor yang memengaruhi jumlah kasus penyakit kusta di Provinsi Jawa Timur pada tahun 2017 adalah persentase rumah sehat dan jumlah puskesmas pada setiap kabupaten/kota di Provinsi Jawa Timur.

\subsection{Saran}

Saran yang dapat peneliti berikan berdasarkan penelitian ini, yaitu diharapkan pemerintah di Provinsi Jawa Timur lebih meningkatkan pelaksanaan penyuluhan akan pentingnya kebersihan dan kesehatan lingkungan agar terhindar dari penyakit kusta serta meningkatkan peran puskesmas dalam memberikan sosialisasi mengenai pemahaman tentang penyakit kusta, seperti penyebab, gejala dan penyembuhan penyakit kusta. Diharapkan pada penelitian selanjutnya lebih memperhatikan faktor-faktor lain yang juga memengaruhi jumlah kasus penyakit kusta.

\section{DAFTAR PUSTAKA}

Anselin, L., 1988. Spatial Econometrics: Methods and Models. Netherland: Kluwer Academic Publisher.

Dewi P.K.K.S., Susilawati, M. \& Sumarjaya, I. W., 2017. Metode Spatial Autoregressive dalam Memodelkan Masyarakat yang Berperilaku MCK di Sungai. E-Jurnal Matematika, 6(4), pp. 233-240.

Dinas Kesehatan Provinsi Jawa Timur, 2018. Profil Kesehatan Provinsi Jawa Timur Tahun 2017, Surabaya: Kementerian Kesehatan RI.

Ernawati, Latra, I. N. \& Purhadi, 2016. Analisis Faktor-Faktor yang Memengaruhi Angka Prevalensi Penyakit Kusta di Jawa Timur dengan Pendekatan Spatial Durbin Model. Jurnal Sains dan Seni ITS, 5(2), pp. D-295D-300.

Fischer, M. M. \& Wang, J., 2011. Spatial Data Analysis: Model, Methods and Technique. Heidelberg: Springer.

LeSage, J. \& Pace, R. K., 2009. Introduction to Spatial Econometrics. London: CRC Press.

Rismawati, D., 2013. Hubungan antara Sanitasi Rumah dan Personal Hygiene dengan Kejadian Kusta Multibasiler. Unnes Journal of Public Health, 2(1), pp. 1-10. 